\title{
KECERNAAN NEUTRAL DETERGEN FIBER (NDF), ACID DETERGENT FIBER (ADF) DAN HEMISELULOSA HIJAUAN PAKAN SECARA IN VITRO
}

\author{
DIGESTIBILITY OF NEUTRAL DETERGEN FIBER (NDF), \\ ACID DETERGENT FIBER (ADF) AND HEMICELLULOSE \\ FORAGE BY IN VITRO
}

\author{
Isnaini Nurkhasanah*, Limbang Kustiawan Nuswantara*, \\ Marry Christiyanto* dan Eko Pangestu* \\ *Laboratorium Ilmu Nutrisi dan Pakan Fakultas Peternakan dan Pertanian Universitas \\ Diponegoro, Semarang. \\ Jl. Prof. H. Soedarto, S.H - Tembalang Semarang, Indonesia 50275 \\ *Email: Isnaininksh@gmail.com \\ Diterima: 6 Februari 2020, Direvisi: 23 Maret 2020, Disetujui: 17 April 2020
}

\begin{abstract}
ABSTRAK
Penelitian ini bertujuan untuk mengetahui pengaruh dari berbagai jenis hijauan terhadap kulitas serat pada pakan kambing. Rancangan percobaan yang digunakan adalah rancangan acak kelompok (RAK) terdiri dari 7 perlakuan jenis bahan pakan hijauan dengan 3 kelompok rumen. Perlakuan meliputi T1: daun Indigofera, T2: daun insulin, T3: daun jambu biji, T4: daun melinjo, T5: daun rambutan, T6: daun singkong dan T7: daun waru. Hasil penelitian menunjukan bahwa jenis hijauan memberikan pengaruh nyata $(\mathrm{P}<0,05)$ terhadap kecernaan kecernaan NDF, ADF dan hemiselulosa. Nilai kecernaan NDF dan ADF tertinggi yaitu daun indigofera $(61,48 \%$ dan 50,42\%). Nilai kecernaan hemiselulosa tertinggi yaitu daun singkong $(74,21 \%)$.
\end{abstract}

Kata Kunci: $A D F$, Hemiselulosa, In vitro, $N D F$, Serat.

\section{ABSTRACT}

This study aims to determine the effect of various types of forage on the fiber qualty for goat. The experimental design used was a randomized complete block design (RCBD) consisting of 7 treatment types of forage feed ingredients with 3 block rumens. The treatment was T1: indigofera leaves, T2: insulin leaves, T3: jambu biji leaves, T4: melinjo leaves, T5: rambutan leaves, T6: singkong leaves and T7: waru leaves. The results showed that the effect types of forage on NDF, $A D F$ and hemicellulose digestibility was significantly different $(P<0,5)$. The highest digestibility value of NDF is Indigofera leaves (61,48\% dan 50,42\%). The highest digestibility value of hemicellulase is Singkong leaves $(74,21 \%)$.

Keywords: $A D F$, Hemiselulosa, In vitro, $N D F$, Fiber. 


\section{PENDAHULUAN}

Pakan merupakan salah satu hal penting yang harus diperhatikan dalam usaha peternakan. Ruminansia seperti kambing memerlukan pakan dengan jenis hijauan dan konsentrat. Pakan jenis hijauan yang diberikan kepada ternak kambing berupa rumput, daun dari berbagai pepohonan dan leguminosa. Ruminansia memiliki kemampuan untuk memanfaatkan sumber karbohidrat yang berasal dari hijauan. Karbohidrat tersebut berupa selulosa, hemiselulosa dan pektin yang berikatan dengan lignin yang ada pada dinding sel tanaman. Hal tersebut berada didalam tanaman sehingga dapat dijadikan sebagai sumber serat kasar (SK) yang dibutuhkan untuk ruminansia (Permana et al., 2015). Berbagai jenis hijauan pakan memiliki kandungan nutrisi yang berbeda - beda. Umumnya pakan jenis hijauan memiliki kandungan serat kasar (SK) yang tinggi.

Kualitas nutrisi pada hijauan yang beragam dapat diamati melalui indikator kecernaan nutrien didalam rumen. Terdapat 3 jenis indikator kecernaan serat seperti kecernaan neutral Detergent fiber (NDF), acid detergent fiber (ADF) dan hemiselulosa. Serat di dalam rumen ruminansia dapat didegradasi oleh bakteri selulolitik menjadi sumber energi untuk ternak (Zain, 2007). Kandungan serat pada leguminosa dibandingkan dengan rumput atau non-leguminosa umumnya lebih rendah dan memiliki kandungan protein yang tinggi, sehingga nilai kecernaan pada hijauan jenis legum lebih tinggi (Hadi et al., 2011). Kandungan SK yang semakin tinggi pada suatu bahan pakan berakibat semakin rendahnya daya cerna bahan pakan tersebut, karena dinding sel pada hijauan tersebut juga semakin tebal dan lebih tahan terhadap degradasi mikroorganisme pencerna serat (Wijayanti et al., 2012). Komponen fraksi serat yang semakin tinggi pada bahan pakan juga menyebabkan mikroba membutuhkan energi lebih banyak untuk mencerna selulosa, hemiselulosa dan lignin, sehingga hal tersebut dapat menurunkan kecernaan. Penelitian ini bertujuan untuk mengetahui pengaruh dari berbagai jenis hijauan terhadap kulitas serat pada pakan kambing.

\section{BAHAN DAN METODE}

Materi yang digunakan yaitu hijauan pakan yang berlaku sebagai perlakuan. Jenis hijauan pakan berupa daun indigofera, daun insulin, daun jambu biji, daun melinjo, daun rambutan, daun singkong, dan daun waru. Cairan rumen yang digunakan dalam pengujian in vitro yaitu cairan rumen kambing Jawarandu yang berasal dari Rumah Potong Hewan (RPH) di Bustaman, Semarang pada waktu pengambilan dan kambing yang berbeda. Penelitian ini dilaksanakan Oktober 2019 sampai dengan Desember 2019. Penelitian dilaksanakan di Laboratorium Ilmu Nutrisi dan Pakan, Fakultas Peternakan dan Pertanian, Universitas Diponegoro, Semarang.

Penelitian ini dilaksanakan dalam dua tahap yaitu tahap persiapan dan tahap perlakuan. Tahap persiapan meliputi pengambilan daun, pengeringan daun, penggilingan daun, analisis proksimat dan analisis kadar serat. Kadar nutrien bahan pakan hijauan dapat dilihat pada Tabel 1. 
Tabel 1.

Kadar Nutrien Bahan Pakan Hijauan.

\begin{tabular}{|c|c|c|c|c|c|c|c|}
\hline \multirow{2}{*}{$\begin{array}{c}\text { Kandungan } \\
\text { Gizi }\end{array}$} & \multicolumn{7}{|c|}{ Bahan Perlakuan } \\
\hline & Indigofera & Insulin & Jambu & Melinjo & Rambutan & Singkong & Waru \\
\hline & & & & $(\%)---$ & . & & --- \\
\hline $\mathrm{BK}$ & 91,72 & 92,34 & 92,26 & 91,02 & 92,21 & 90,19 & 91,01 \\
\hline $\mathrm{BO}$ & 91,68 & 82,33 & 91,61 & 89,97 & 93,22 & 91,88 & 87,23 \\
\hline PK & 11,61 & 23,98 & 8,73 & 21,45 & 8,67 & 18,85 & 12,55 \\
\hline LK & 4,99 & 4,80 & 3,95 & 4,93 & 4,53 & 6,62 & 6,00 \\
\hline BETN & 25,63 & 21,90 & 32,10 & 23,59 & 33,01 & 19,28 & 23,95 \\
\hline SK & 49,44 & 31,65 & 46,84 & 40,01 & 47,02 & 47,13 & 44,72 \\
\hline Karbohidrat & 75,08 & 53,55 & 78,94 & 63,60 & 80,03 & 66,41 & 68,68 \\
\hline NFC & 23,43 & 7,71 & 11,27 & 18,62 & 11,82 & 12,12 & 12,71 \\
\hline NDF & 51,65 & 45,84 & 67,66 & 44,97 & 68,20 & 54,29 & 55,97 \\
\hline $\mathrm{ADF}$ & 43,33 & 21,98 & 59,98 & 29,21 & 62,39 & 48,71 & 49,09 \\
\hline Hemiselulosa & 8,32 & 23,86 & 7,69 & 15,77 & 5,81 & 5,58 & 6,88 \\
\hline Selulosa & 23,54 & 14,12 & 27,99 & 20,71 & 28,56 & 27,47 & 34,33 \\
\hline Lignin & 7,96 & 4,63 & 27,34 & 8,28 & 28,99 & 10,07 & 10,39 \\
\hline Silika & 11,80 & 3,24 & 4,64 & 0,22 & 4,82 & 11,18 & 4,37 \\
\hline Tanin & 4,71 & 6,81 & 0,97 & 1,10 & 1,30 & 1,32 & 1,62 \\
\hline $\mathrm{Abu}$ & 8,32 & 17,67 & 8,39 & 10,03 & 6,78 & 8,12 & 12,77 \\
\hline
\end{tabular}

Sumber: Isnaini et al. (2019).

Tahap perlakuan dan pengambilan data dilakukan dengan cara in vitro menggunakan metode Tilley dan Terry (1963). Uji kecernaan serat NDF, ADF dan Hemiselulosa menggunakan metode Van Soest (1994).

Parameter yang diamati meliputi kecernaan NDF, ADF dan Hemiselulosa. Pengukuran parameter dilakukan dengan cara melakukan analisis pada residu dari hasil uji in vitro. Pengukuran kecernaan NDF dilakukan dengan cara sampel sebanyak 14 buah/kelompok, dimasukkan ke dalam beaker glass $250 \mathrm{ml}$. Larutan detergen netral (NDS) sebanyak $100 \mathrm{ml}$ dan $0,5 \mathrm{~g} \mathrm{Na}_{2} \mathrm{SO}_{3}$ ditambahkan ke dalam beaker glass yang berisi sampel. Sampel lalu dipanaskan sampai mendidih selama 1 jam dengan suhu yang terjaga. Sampel yang telah selesai dipanaskan kemudian disaring dengan krusibel yang sudah diketahui beratnya dengan bantuan pompa vakum. Proses penyaringan dilakukan dengan ditambahkan beberapa larutan, pertama sampel dicuci dengan air panas bersuhu $\pm 80^{\circ} \mathrm{C}$, lalu dengan acetone atau $\mathrm{N}$-Hexan dan diulangi sebanyak dua kali. Sampel yang telah selesai dilakukan penyaringan kemudian dioven dengan suhu $105^{\circ} \mathrm{C}$ selama 8 jam. Sampel kemudian ditimbang dan dihitung kadar NDF. Kadar NDF dihitung dengan rumus:

Kadar NDF $=\frac{\mathrm{A}-\mathrm{B}}{\mathrm{C} \times \mathrm{D}} \times 100 \%$

Keterangan :

A : berat krusibel + sampel

$\mathrm{B}$ : berat krusibel

$\mathrm{C}$ : berat kering udara sampel

$\mathrm{D}: \% \mathrm{BK}$ sampel

Rumus kecernaan NDF :

Kec. $\mathrm{NDF}=\frac{\mathrm{A}-(\mathrm{B}-\mathrm{C})}{\mathrm{A}} \times 100 \%$

Keterangan : 
A : berat NDF pakan

$B$ : berat NDF residu

$\mathrm{C}$ : berat NDF blanko

Pengukuran kecernaan ADF dilakukan dengan cara sampel dimasukkan ke dalam beaker glass $250 \mathrm{ml}$, ditambahkan $100 \mathrm{ml}$ larutan detergen asam (ADS) dan sampel dipanaskan sampai mendidih dengan suhu yang terjaga. Sampel disaring dengan krusibel yang sudah diketahui beratnya dengan bantuan pompa vakum, dan dilanjutkan sampel dicuci dengan air panas bersuhu \pm $80^{\circ} \mathrm{C}$ kemudian dicuci dengan acetone atau N-Hexan dan diulangi sebanyak dua kali. Sampel dioven dengan suhu $105^{\circ} \mathrm{C}$ selama 8 jam kemudian sampel ditimbang dan kadar ADF dihitung. Kadar ADF dapat dihitung dengan rumus:

Kadar $\mathrm{ADF}=\frac{\mathrm{A}-\mathrm{B}}{\mathrm{C} \times \mathrm{D}} \times 100 \%$

Keterangan :

A : berat krusibel + sampel

$\mathrm{B}$ : berat krusibel

$\mathrm{C}$ : berat kering udara sampel

D : \%BK sampel

Rumus kecernaan ADF :

Kec. $\mathrm{ADF}=\frac{\mathrm{A}-(\mathrm{B}-\mathrm{C})}{\mathrm{A}} \times 100 \%$

Keterangan :

A : berat ADF pakan

$\mathrm{B}$ : berat $\mathrm{ADF}$ residu
$\mathrm{C}$ : berat ADF blanko

Pengukuran kadar hemiselulosa dapat dilakukan dengan perhitungan rumus sebagai berikut:

Hemiselulosa $=$ kadar NDF - kadar ADF

Pengukuran kecernaan Hemiselulosa dengan rumus :

Kec. Hemiselulosa $=\frac{A-(B-C)}{A} \times 100 \%$

Keterangan:

A : berat hemiselulosa pakan

$\mathrm{B}$ : berat hemiselulosa residu

C : berat hemiselulosa blanko

Rancangan percobaan yang digunakan adalah rancangan acak kelompok (RAK) dengan perlakuan 7 jenis bahan pakan hijauan dengan 3 kelompok rumen yang diambil dari rumah pemotongan hewan (RPH) pada waktu pengambilan dan kambing yang berbeda. Data yang diperoleh pada penelitian ini dianalisis dengan analisis sidik ragam (analysis of variance/ ANOVA) kemudian dilanjutkan dengan uji lanjut ganda Duncan.

\section{HASIL DAN PEMBAHASAN}

Hasil rata - rata kecernaan NDF, ADF dan Hemiselulosa pada berbagai jenis hijauan pakan kambing yang dianalisis secara in vitro diapat dilihat pada Tabel 2.

Tabel 2.

Rata-rata Kecernaan Neutral Detergen Fiber (NDF) Hijauan Pakan Kambing.

\begin{tabular}{lccc}
\hline Perlakuan & NDF & ADF & Hemiselulosa \\
\hline & --- a & $50,42^{\mathrm{a}}$ & $58,45^{\mathrm{b}}$ \\
Indigofera & $61,48^{\mathrm{a}}$ & $45,92^{\mathrm{ab}}$ & $60,40^{\mathrm{b}}$ \\
Insulin & $46,55^{\mathrm{b}}$ & $21,44^{\mathrm{d}}$ & $47,20^{\mathrm{c}}$ \\
Jambu & $28,58^{\mathrm{d}}$ & $35,79^{\mathrm{bc}}$ & $24,93^{\mathrm{e}}$ \\
Melinjo & $37,16^{\mathrm{c}}$ & $12,61^{\mathrm{e}}$ & $42,60^{\mathrm{c}}$ \\
Rambutan & $31,37^{\mathrm{cd}}$ & $32,08^{\mathrm{c}}$ & $74,21^{\mathrm{a}}$ \\
Singkong & $30,48^{\mathrm{d}}$ & $17,44^{\mathrm{de}}$ & $32,82^{\mathrm{d}}$ \\
Waru & $16,31^{\mathrm{e}}$ & &
\end{tabular}

Superskrip yang berbeda pada kolom yang sama menunjukan perbedaan nyata $(\mathrm{P}<0,05)$ 
Pengujian tingkat kekerasan pakan dilaksanakan dengan diuji menggunakan alat pellet hardness tester. Pellet yang baik memiliki nilai hardness berkisar 3,92 sampai dengan 6,37. Kekerasan tersebut dipengaruhi oleh ukuran dan bahan pellet. Komposisi bahan pakan, binder/perekat yang digunakan dan proses conditioning merupakan faktor yang dapat mempengaruhi hardness.

\section{Uji Kadar Air Pakan Pellet}

Nilai kadar air pakan pellet disajikan pada Tabel 3.

Tabel 3.

Rataan Hasil Kadar Air pada Berbagai Pakan Ternak Bentuk Pellet

\begin{tabular}{cc}
\hline \hline Pakan Pellet & Kadar Air \\
\hline & $-----(\%)-----$ \\
P1 & $13,98 \pm 0,16$ \\
P2 & $15,05 \pm 0,08$ \\
P3 & $13,72 \pm 0,27$ \\
P4 & $16,12 \pm 0,29$ \\
P5 & $7,78 \pm 0,03$ \\
P6 & $8,22 \pm 0,04$ \\
P7 & $12,30 \pm 0,05$ \\
P8 & $15,82 \pm 0,18$ \\
\hline
\end{tabular}

\section{Kecernaan Neutral detergen fiber (NDF)}

Nilai kecernaan NDF dari tertinggi hingga terendah berturut - turut yaitu Indigofera $(61,48 \%)$, Insulin $(46,55 \%)$, Melinjo (37,16\%), Rambutan (31,37\%), Singkong (30,48\%), Jambu (28,58\%), dan Waru (16,31\%). Hasil analisis ragam menunjukkan bahwa jenis hijauan yang berbeda memberikan pengaruh nyata $(\mathrm{P}<0,05)$ terhadap kecernaan NDF. Uji lanjut Ganda Duncan menunjukkan bahwa kecernaan NDF pada daun Indigofera lebih tinggi $(\mathrm{P}<0,05)$ dengan hijauan pakan lainnya. Daun singkong memiliki nilai kecernaan NDF tidak berbeda nyata dengan daun Rambutan dan daun Jambu. Daun Waru memiliki nilai kecernaan NDF lebih rendah $(\mathrm{P}<0,05)$ dengan hijauan pakan lainnya.

Hasil dari uji in vitro daun Indigofera, daun insulin dan daun melinjo memiliki nilai kecernaan NDF yang lebih tinggi dibandingkan dengan jenis hijauan yang lain. Kecernaan dapat tinggi karena kandungan NDF, lignin, selulosa dan hemiselulosa pada hijauan tersebut lebih rendah dibandingkan hijauan yang lain (Tabel 1). Kandungan serat yang semakin kecil dapat meningkatkan kecernaan karena mikroba rumen akan lebih mudah mencerna. Wahyono et al. (2019) menyatakan bahwa semakin rendah komponen fraksi serat maka semakin kecil pula energi yang diperlukan mikroba untuk mencerna selulosa, hemiselulosa dan lignin, sehingga hal tersebut dapat meningkatkan kecernaan. Kadar lignin pada pakan merupakan salah satu faktor yang mempengaruhi kecernaan. Kadar lignin pada daun indigofera, daun insulin dan daun melinjo diketahui lebih rendah dibanding hijauan lain. Kadar lignin yang rendah dapat menyebabkan nilai kecernaan tinggi. Siswanto et al. (2016) menyatakan bahwa semakin rendah kandungan lignin pada suatu bahan pakan maka kecernaan akan meningkat, karena lignin akan membentuk senyawa komplek 
lignohemiselulosa dan lignoselulosa yang sulit dicerna.

Hasil dari uji in vitro daun Waru memiliki nilai kecernaan yang paling rendah dibandingkan dengan jenis hijauan yang lain yaitu 16,31 persen. Kecernaan NDF pada daun Waru yang rendah diduga karena kandungan lemak kasar (LK) pada waru lebih besar dibanding hijauan yang lain (Tabel 1). Kandungan lemak yang terlalu tinggi pada pakan dapat berdampak pada penurunan $\mathrm{pH}$ rumen, sehingga menyebabkan perkembangan dan aktivitas mikroba rumen terhambat, hal tersebut dapat menurunkan kecernaan serat. Priyanto et al. (2017) menyatakan bahwa meningkatnya penambahan asam lemak dalam pakan dapat menghambat aktivitas mikroba rumen sehingga kecernaan menurun. Kadar lemak yang tinggi dapat mengganggu sistem fermentasi dalam rumen, karena lemak dapat melekat pada mikroba rumen sehingga mikroba yang tidak mempunyai enzim lipolisis seperti protozoa akan mati. Kondisi tersebut dapat meningkatkan pertumbuhan mikroba karena mengurangi siklus $\mathrm{N}$ bakteri dalam rumen (Adawiyah et al., 2007).

\section{Kecernaan Acid detergent fiber (ADF)}

Nilai kecernaan ADF dari tertinggi hingga terendah berturut-turut yaitu Indigofera (50,42\%), Insulin (45,92\%), Melinjo (35,79\%), Singkong $(32,08 \%)$, Jambu (21,44\%), Waru $(17,44 \%)$, dan Rambutan (12,61\%). Hasil analisis ragam menunjukkan bahwa jenis hijauan memberikan pengaruh nyata $(\mathrm{P}<0,05)$ terhadap kecernaan ADF. Uji lanjut Ganda Duncan menunjukkan bahwa kecernaan ADF pada daun Indigofera tidak berbeda nyata dengan daun Insulin namun berbeda nyata dengan jenis hijauan lainnya. Daun Waru memiliki nilai tidak berbeda nyata dengan daun Rambutan, namun berbeda nyata dengan jenis hijauan lainnya.
Nilai kecernaan ADF Indigofera tidak berbeda nyata dengan daun insulin dapat dikarenakan memiliki rasio antara ADF dan lignin yang hampir sama yaitu 5,45:1 dan 4,74:1. Kadar lignin memiliki korelasi negatif dengan kecernaan ADF. Semakin rendah kadar lignin maka kecernaan akan meningkat, karena lignin tidak dapat dicerna oleh mikroba rumen dan dapat mengganggu kecernaan (Hambakodu et al., 2020).

Daun Jambu, Rambutan dan Waru memiliki kecernaan ADF yang terrendah diduga karena jenis hijauan tersebut memiliki kadar ADF tinggi dan kadar protein kasar rendah (Tabel 1). Kadar ADF yang tinggi dapat menyebabkan kecernaan ADF rendah karena kecernaan ADF memiliki korelasi negatif dengan kadar ADF. Melati dan Sunarno (2016) menyatakan bahwa kadar ADF yang semakin tinggi menunjukkan kualitas dari bahan pakan yang semakin turun sehingga menyebabkan kecernaan ADF juga menurun. Kandungan protein yang rendah dapat menurunkan kecernaan ADF karena pertumbuhan dan aktivitas mikroba rumen dalam terhambat. Kandungan protein yang rendah pada bahan pakan dapat menyebabkan konsentrasi amonia dan $\mathrm{pH}$ dalam rumen dapat menurun. Konsentrasi amonia yang rendah dapat menghambat pertumbuhan dan aktivitas mikroba dalam mencerna pakan didalam rumen, hal tersebut berakibat pada menurunnya kecernaan ADF (Siswanto et al., 2016). Rahalus et al. (2014) menyatakan bahwa kandungan protein yang rendah dapat menyebabkan $\mathrm{pH}$ rumen menurun sehingga menyebabkan mikroba rumen tidak berkembang dengan baik dan tidak optimal dalam mencerna pakan dan mengakibatkan kecernaan serat menurun. 


\section{Kecernaan hemiselulosa}

Nilai kecernaan Hemiselulosa dari tertinggi hingga terendah berturut-turut yaitu daun Singkong $(74,21 \%)$, Insulin $(60,40 \%)$, Indigofera (58,45\%), Jambu (47,20\%), Rambutan $(42,60 \%)$, Waru $(32,82 \%)$ dan Melinjo $(24,93 \%)$. Hasil analisis ragam menunjukkan bahwa jenis hijauan memberikan pengaruh nyata $(\mathrm{P}<0,05) \quad$ terhadap kecernaan Hemiselulosa. Uji lanjut Ganda Duncan menunjukkan bahwa kecernaan Hemiselulosa daun Singkong berbeda nyata dengan semua jenis daun. Daun Insulin memiliki nilai tidak berbeda nyata dengan daun Indigofera, namun berbeda nyata dengan jenis hijauan yang lain. Daun Rambutan memiliki nilai tidak berbeda nyata dengan daun Singkong. Daun Waru memiliki nilai berbeda nyata dengan semua jenis daun. Daun Melinjo memiliki nilai berbeda nyata dengan semua jenis daun.

Indigofera dan daun Insulin memiliki nilai kecernaan NDF yang tinggi, namun kecernaan hemiselulosanya lebih rendah dibandingkan daun Singkong hal ini dapat terjadi diduga karena daun Singkong memiliki kadar protein yang cukup tinggi dan kadar hemiselulosa yang rendah dibandingkan hijauan lain (Tabel 1). Kadar hemiselulosa yang rendah dapat mempercepat kecernaan hemiselulosa karena mikroba dapat lebih cepat dalam mencerna hemiselulosa. Susanti et al. (2020) menyatakan bahwa kandungan hemiselulosa yang tinggi dapat meng- akibatkan penurunan kecernaan hemiselulosa karena mikroba membutuhkan waktu untuk mendegradasi lebih lama. Faktor lain yang dapat menyebabkan nilai kecernaan hemiselulosa pada daun singkong lebih tinggi yaitu karena gula penyusun hemiselulosa pada daun singkong seperti kadar xilosa yang lebih rendah dan kadar arabinose lebih tinggi, sehingga kecernaan hemiselulosanya lebih tinggi dibanding dengan daun Indigofera. Turangan et al. (2018) menyatakan bahwa kecernaan dinding sel dapat dipengaruhi oleh perbedaan rasio arabinose : xylosa. Fraksi serat dengan rasio arabinose : xylosa yang lebih tinggi cenderung memiliki degradasi yang lebih tinggi, karena rantai cabang arabinosa yang tinggi dapat menurunkan kecenderungan pembentukan ikatan non kovalen antara xylose dengan selulosa, sehingga dapat menyebabkan dinding sel jadi lebih lunak dan dapat meningkatkan kecernaan (Maaruf dan Paputungan, 2017).

\section{KESIMPULAN}

Berdasarkan hasil penelitian disimpulkan bahwa ada pengaruh pada kecernaan serat terhadap kandungan fraksi serat yang semakin rendah. Semakin rendah kandungan fraksi serat maka kualitas pakan akan semakin baik karena pakan mudah untuk dicerna. Daun Indigofera, daun Insulin dan daun Melinjo berpotensi besar untuk diberikan sebagai pakan kambing karena memiliki nilai kecernaan serat yang tinggi. 


\section{DAFTAR PUSTAKA}

Adawiyah, T. Sutardi, T. Toharmat, W. Manalu, N. Ramli dan U. H. Tanuwiria. 2007. Respons terhadap suplementasi sabun mineral dan mineral organik serta kacang kedelai sangrai pada indikator fermentabilitas ransum dalam rumen domba. J. Media Peternakan. 30 (1): 63-70.

Hadi, R.H., Kustantinah, dan H. Hartadi. 2011. Kecernaan in sacco hijauan leguminosa dan hijauan nonleguminosa dalam rumen Sapi

Peranakan Ongole. Buletin Peternakan 35(2):79-85.

Hambakodu, M., A. Kaka, dan Y. T. Ina. 2020. Kajian in vitro kecernaan fraksi serat hijauan tropis pada media cairan rumen kambing. J. Ilmu dan Teknologi Peternakan Tropis. 7 (1): 29-34.

Maaruf, K. dan U. Paputungan. 2017. Comparison of protein and cell wall degradation of selected tropical and temperate roughages. Livestock Research for Rural Development. 29 (6)

Melati, I. dan M. T. D. Sunarno. 2016. Pengaruh enzim selulosa Bacillus subtilis terhadap penurunan serat kasar kulit ubi kayu untuk bahan baku pakan ikan. Widyariset. 2(1): $57-66$.

Permana, H., S. Chuzaemi, Marjuki dan Mariyono. 2015. Pengaruh pakan dengan level serat kasar berbeda terhadap konsumsi, kecernaan dan karakteristik VFA pada sapi Peranakan Ongole. Analisis hasil penelitian dan pengabdian Fakultas Peternakan Universitas Brawijaya, Malang. Hal. 1-10.

Priyanto, A., A. Endraswati, Rizkyanshah, N. C. Febriyani, T. Nopiansyah dan L. K. Nuswantara. 2017. Pengaruh pemberian minyak jagung dan suplementasi urea pada ransum terhadap profil cairan rumen $\left(\mathrm{KcBK}, \mathrm{KcBO}, \mathrm{pH}, \mathrm{N}-\mathrm{NH}_{3}\right.$ dan total mikroba rumen). J. Ilmu Ternak. 17 (1): 1-9.

Rahalus, R., B. Tulung, K. Maaruf dan F. R. Wolayan. 2014. Pengaruh penggunaan konsentrat dalam pakan rumput benggala (Panicum maximum) terhadap kecernaan NDF dan ADF pada kambing lokal. J. Zootek. 34 (1): 75-82.

Siswanto, D., B. Tulung, K. Maaruf, M. R. Waani dan M. M. Tindangen. 2016. Pengaruh pemberian rumput raja (Pennisetum purpupoides) dan tebon jagung terhadap kecernaan NDF dan ADF pada sapi PO pedet jantan.

J. Zootek. 36 (2) 379-386.

Susanti, D., N. Jamarun, F. Agustin, T. Astuti dan G. Yanti. 2020. Kecernaan in-vitro fraksi serat kombinasi pucuk tebu dan titonia fermentasi sebagai pakan ruminansia. J. Agripet. 20 (1): 8695.

Tilley, J.M.A. dan R. A. Terry. 1963. A two stage technique for the in vitro digestion of forage crops. J. British Grass. Soc. 18: 104 - 111.

Turangan, G. G., B. Tulung, Y. R. L. Tulung dan M. R. Waani. 2018. Kecernaan NDF dan ADF yang mendapat suplementasi Urea Molasses Multinutrient Block (UMMB) dari beberapa jenis limbah pertanian dan rumput lapang pada sapi Peranakan Ongole (PO). J. Zootek. 38 (2):320-328.

Van Soest, P. J. 1994. Nutritional Ecology of the Ruminant. 2nd Ed. Cornell University Press, Ithaca.

Wahyono, T., E. Jatmiko, Firsoni, S. N. W. Hardani dan E. Yunita. 2019. 
Evaluasi nutrien dan kecernaan in vitro beberapa spesies rumput lapangan tropis di Indonesia. J. Sains Peternakan. 17 (2): 17-23.

Wijayanti, E., F. Wahyono dan Surono. 2012. Kecernaan nutrien dan fermentabilitas pakan komplit dengan level ampas tebu yang berbeda secara in vitro. J. Animal Agricultural. 1 (1): 167 - 179.

Zain, M. 2007. Optimalisasi penggunaan serat sawit sebagai pakan serat alternatif dengan suplementasi daun ubi kayu dalam ransum ruminansia. J. Indonesian Tropical Animal Agriculture. 32 (2): 100 105 